\title{
PEMERIKSAAN STATUS KESEHATAN HEWAN KURBAN DALAM SITUASI WABAH COVID-19 DI KABUPATEN MANOKWARI
}

\author{
Monitoring the Health Status of Qurban Animals in a Covid-19 Outbreak Situation \\ in Manokwari Regency
}

\author{
Priyo Sambodo*, Isti Widayati, Dwi Nurhayati, Alnita Baaka, Rizki Arizona \\ Fakultas Peternakan, Universitas Papua, Manokwari, Papua Barat
}

Article history

Received: Jul 1, 2020;

Accepted: Okt 20, 2020

* Corresponding author:

E-mail:

drh_priyo01@yahoo.com

DOI: https://doi.org/10.465

49/igkojei.v1i1.140

\section{ABSTRACT}

The activity was carried out to determine the health status of qurban animals and the worthiness of the qurban meat during eid al-adha in Manokwari Regency through antemortem and postmortem examinations and the application of health protocols during the Covid-19 pandemic. Six hundred fifty-six of beef cattles were examined to determine their general condition, eye mucosa, anus and feces (ante-mortem) and liver and rumen by direct observation (inspection) of the presence of worm parasites (post-mortem). Covid-19 health protocol observations were carried out on: butchers, meat officers and facilities around the activity. Data were analyzed descriptively and presented in percent and figures. Average Body Condition Score beef cattle examined were 3 to 4. Locomotion and skin turgor were normal. In general, the examined meat was fit for consumption. The eye mucosal color in the examined cows was pink. The anus condition of all the cows examined is clean and the stool consistency is soft. A total of 106 livers (16.16\%) had fasciolosis and 89 rumens (13.57\%) were positively infested with Paramphistomum sp. Most of the slaughter places have carried out a health protocols with body temperature checks, must washing their hands when entering the slaughtering area and most of the workers have wearing a mask.

Keywords: Qurban Animals; Heartworms; Covid-19

\section{ABSTRAK}

Kegiatan ini bertujuan untuk mengetahui status kesehatan hewan kurban dan kelayakan daging kurban di Kabupaten Manokwari melalui pemeriksaan antemortem dan postmortem dan penerapan protokol kesehatan selama wabah covid-19. Hewan yang diperiksa adalah sapi dengan jumlah sebanyak 656 ekor. Pemeriksaan terdiri atas ante-mortem meliputi pemeriksaan keadaan umum, mukosa mata, anus dan feses dengan cara inspeksi dan pemeriksaan postmortem, meliputi: hati dan rumen yang dilakukan dengan pengamatan langsung (inspeksi) keberadaan parasit cacing dalam organ periksa. Pengamatan protokol kesehatan covid-19 dilakukan pada: petugas jagal, petugas daging, petugas jeroan dan fasilitas disekitar kegiatan berlangsung. Data dianalisis secara deskriptif dan disajikan dalam persen dan gambar. Rerata Body Condition Score (BCS) sapi yang disembelih adalah 3 sampai 4. Lokomosi 100\% dan turgor kulit normal. Secara umum daging yang diperiksa layak dikonsumsi. Rerata warna mukosa mata pada sapi yang diperiksa adalah merah muda. Keadaan anus dari seluruh sapi yang diperiksa adalah bersih dan konsistensi fesesnya lunak. Sebanyak 106 organ hati sapi $(16,16 \%)$ yang diperiksa mengalami fasciolosis dan sebanyak 89 rumen $(13,57 \%)$ positif terinfestasi Paramphistomum sp. Sebagian besar tempat penyembelihan telah melakukan protokol kesehatan berupa pemeriksaan suhu tubuh, wajib cuci tangan saat memasuki area penyembelihan dan sebagian besar petugas jagal, petugas daging dan petugas 
jeroan telah mengenakan masker.

Kata Kunci: Hewan Kurban; Cacing Hati; Covid-19

\section{PENDAHULUAN}

Hari Raya Kurban merupakan salah satu hari besar bagi umat Islam. Di Kabupaten Manokwari, pada setiap perayaan hari raya tersebut dilakukan penyembelihan hewan kurban, berupa ternak sapi dan kambing dan daging hewan kurban tersebut didistribusikan kepada masyarakat untuk dikonsumsi tak terkecuali pada masa wabah Covid-19 ini. Pada tahun 2020 ini jumlah hewan kurban yang disembelih di masjid-masjid maupun lokasi penyembelihan di Kabupaten Manokwari, berjumlah 656 ekor sapi (Dinas Pertanian dan Ketahanan Pangan Kab. Manokwari, 2020).

Pada tahun ini, pelaksanaan penyembelihan hewan kurban mendapat perhatian lebih dari pemerintah terkait dengan merebaknya wabah Covid-19. Pemerintah melalui Dirjen PKH Kementerian Pertanian (2020) mengeluarkan panduan pelaksanaan penyembelihan hewan kurban yang dititikberatkan pada mitigasi resiko dari pemilihan hewan kurban, sarana pemotongan hewan kurban, penerapan kesejahteraan hewan, penjaminan kesehatan hewan dan daging, penanganan daging dan jeroan yang higienis dan penanganan limbah, sehingga pelaksanaan penyembelihan hewan kurban berjalan aman. Protokol kesehatan yang diterapkan terdiri atas: jaga jarak fisik, penerapan hygiene personal, pemeriksaan kesehatan awal, penerapan hygiene dan sanitasi. Selain itu itu MUI (2020) juga mengeluarkan fatwa sehubungan dengan protokol kesehatan bagi petugas selama penyembelihan hewan kurban yang mengacu pada protokol kesehatan dari pemerintah, yaitu: menerapkan physical distancing, meminimalisir terjadinya kerumunan, memakai masker, mencuci tangan dengan sabun, diutamakan melaksanakan pemotongan di RPH, dan penerapan protokol kesehatan pada saat pendistribusian daging kurban.

Secara umum, pelaksanaan pemeriksaan hewan kurban pada tahun ini sama seperti tahun-tahun sebelumnya, yaitu dititikberatkan pada penjaminan kesehatan hewan dan daging melalui pemeriksaan ante dan post-mortem. Salah satu syarat utama ternak yang dapat dijadikan sebagai hewan kurban adalah sehat sehingga kriteria daging ASUH (Aman, Sehat, Utuh dan Halal) sebagai syarata daging yang layak untuk dikonsumsi akan dapat terpenuhi. Cara pemeliharaan ternak sapi di Kabupaten Manokwari dan sekitarnya yang masih bersifat tradisional, yaitu dengan cara diumbar dan belum diperhatikannya pencegahan dan pengobatan penyakit, khususnya yang bersumber dari parasit, maka diyakini bahwa ternak yang dijadikan hewan kurban beresiko terhadap penyakit, khususnya yang disebabkan oleh parasit.

Berdasarkan kenyataan tersebut di atas, maka monitoring pelaksanaan penerapan protokol kesehatan pada saat penyembelihan hewan kurban dan pemeriksaan status kesehatan hewan kurban di kabupaten Manokwari sangat penting untuk dilakukan, sebagai salah satu upaya menyediakan daging hewan kurban yang memenuhi kriteria ASUH dan sekaligus mencegah penyakit food borne diseases maupun kejadian zoonosis dengan tetap mencegah penyebaran wabah covid-19. Kegiatan ini bertujuan untuk mengetahui status kesehatan hewan kurban dan kelayakan daging kurban di Kabupaten Manokwari melalui pemeriksaan antemortem dan postmortem dan penerapan protokol kesehatan selama wabah covid-19.

\section{METODE}

Kegiatan dilakukan pada tanggal 31 Juli - 1 Agustus 2020 di 55 lokasi penyembelihan hewan kurban di Kabupaten Manokwari. Hewan yang diperiksa adalah sapi sebanyak 656 ekor.

\section{PEMERIKSAAN ANTE-MORTEM}

Pemeriksaan ante-mortem meliputi pemeriksaan keadaan umum, mukosa mata, anus dan feses dengan cara inspeksi (Gambar 1a). 


\section{PEMERIKSAAN POST-MORTEM}

\section{HATI}

Pemeriksaan ini dilakukan dengan pengamatan langsung (inspeksi) keberadaan parasit cacing dalam organ periksa. Organ hati disayat melintang dan atau membujur pada setiap lobus hati dan dilakukan inspeksi untuk mengetahui ada tidaknya parasit cacing (Gambar 1b). Cacing dan bagian organ hati yang terinfeksi parasit cacing diafkir.

\section{RUMEN}

Rumen disayat membujur sehingga mukosa rumen terlihat (Gambar 1c). Seluruh permukaan mukosa rumen diinspeksi untuk keberadaan parasit cacing. Selanjutnya parasit cacing yang teramati disingkirkan dari permukaan mukosa rumen. Bagian rumen yang ditempeli oleh cacing diafkir.
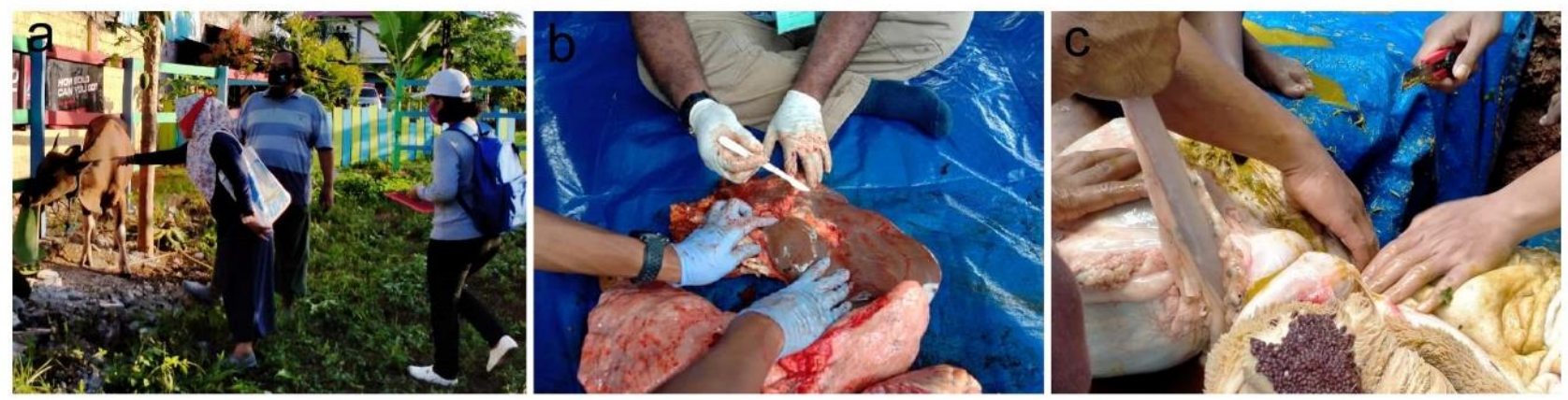

Gambar 1. Tatacara pemeriksaan ante dan post mortem. (a). Menilai BCS; (b) Membuat sayatan pada hati; (c) Membuat sayatan pada rumen.

\section{PENGAMATAN PROTOKOl KesehatAN COVID-19}

Pengamatan dilakukan pada: petugas jagal, petugas daging, petugas jeroan dan fasilitas disekitar kegiatan berlangsung.

ANALISA DATA

Data dianalisis secara deskriptif dan disajikan dalam persen dan gambar.

\section{HASIL DAN PEMBAHASAN}

Monitoring pelaksanaan penerapan protokol kesehatan pada saat penyembelihan hewan kurban dan pemeriksaan status kesehatan hewan kurban di Kabupaten Manokwari ini merupakan bentuk pengabdian masyarakat dari staf dosen Fakultas Peternakan UNIPA bekerjasama dengan petugas dari Dinas Pertanian dan Ketahanan Pangan Kabupaten Manokwari.

Secara umum, berdasarkan pemeriksaan fisik daging, seluruh daging kurban yang diperiksa layak untuk dikonsumsi. Daging sapi segar memiliki ciri-ciri sebagai berikut: warna merah terang dan lemaknya berwarna kekuningan, kadar airnya sedikit, apabila dipencet tidak mengeluarkan air dan aroma amis segar (Hadi et al., 2011).

\section{PEMERIKSAAN ANTE-MORTEM}

Sebanyak 656 ekor sapi telah diperiksa sebelum dilakukan penyembelihan. Secara terperinci hasil pemeriksaan ante-mortem adalah sebagai berikut:

\section{KEADAAN UMUM, MUKOSA MATA, KEADAAN ANUS DAN FESES}

Rerata Body Condition Score (BCS) sapi yang disembelih adalah 3 sampai 4 (Gambar 2a). Lokomosi 100\% normal (tidak ada kepincangan) dan turgor kulit normal (tidak dehidrasi). Rerata warna mukosa mata pada sapi yang diperiksa adalah normal (merah muda) (Gambar 2b). Keadaan anus dari seluruh sapi yang diperiksa adalah bersih (tidak terjadi diare) (Gambar 2c) dan konsistensi fesesnya lunak (Gambar 2d).

Menurut Tainmeta et al. (2016), nilai BCS hewan kurban masuk dalam kategori sedang sampai gemuk. Nilai BCS, lokomosi dan turgor kulit hewan yang diperiksa ini telah memenuhi syarat untuk 
disembelih sebagai hewan kurban, sebagaimana diketahui bahwa hewan kurban harus memenuhi standar kesehatan hewan yang ditetapkan oleh lembaga yang memiliki wewenang (MUI, 2009).
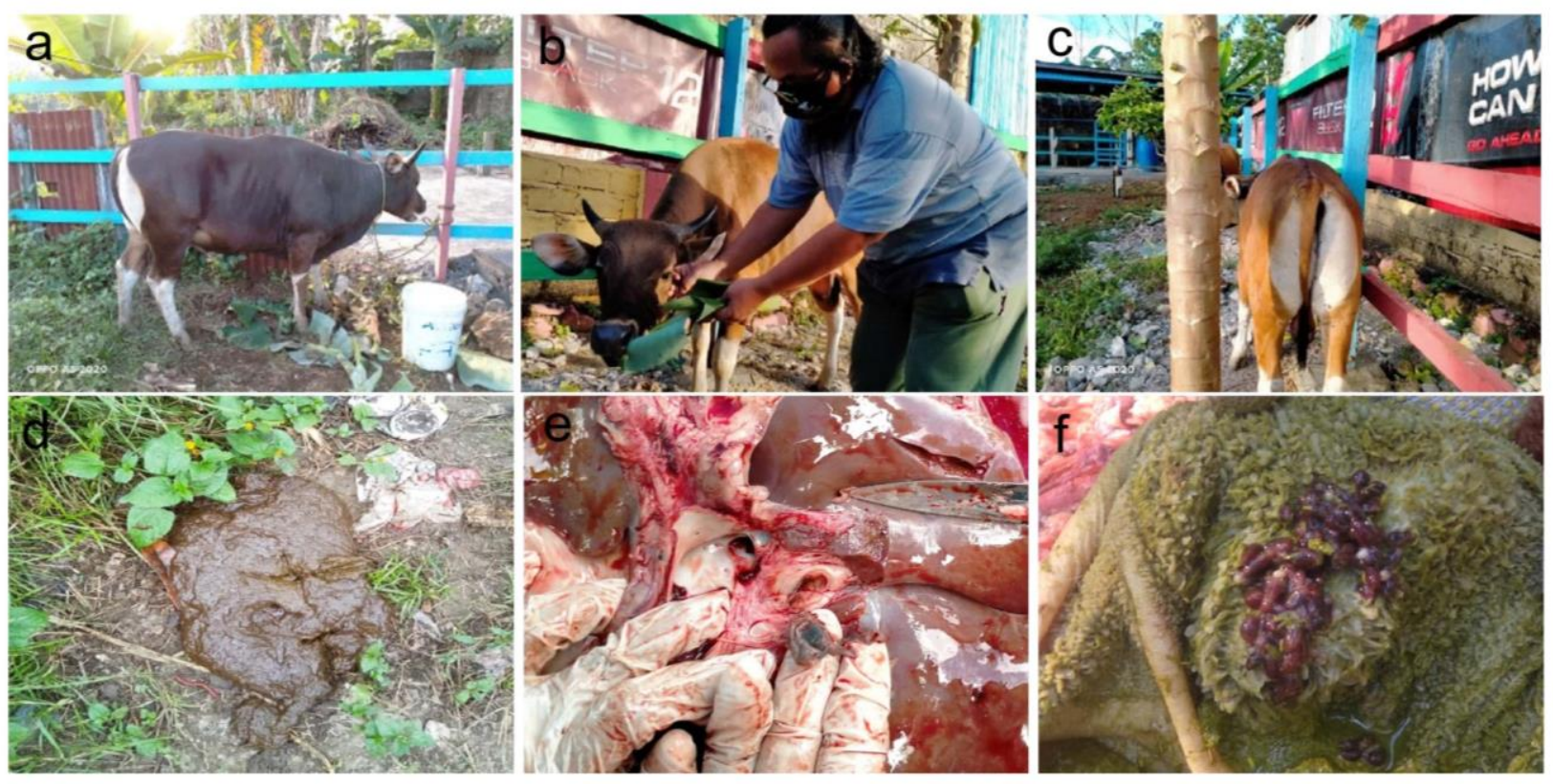

Gambar 2. Hasil pemeriksaan ante dan post mortem. (a) BCS dengan nilai 4; (b) Mukosa mata pink;

(c) Keadaan anus bersih; (d) konsistensi feses normal; (e) Fasciola spp pada hati; (f)

Paramphistomum sp pada rumen

\section{PEMERIKSAAN POST-MORTEM}

\section{HATI}

Sebanyak 106 organ hati sapi $(16,16 \%)$ (Gambar 3) yang diperiksa positif terhadap cacing hati (Gambar 2e) atau sapi mengalami fasciolosis. Hasil ini lebih kecil dibandingkan dengan hasil penelitian Purwaningsih et al. (2017) yang menyebutkan bahwa prevalensi Fasciola sp di Kabupaten Manokwari pada tingkat ternak sebesar 34,96\%, sementara prevalensi pada tingkat peternak sebesar $66,14 \%$. Perbedaan ini diyakini disebabkan karena perbedaan bahan pemeriksaan dimana Purwaningsih et al. (2017) menggunakan feses dalam pemeriksaan. Graham-Brown et al. (2020) menyebutkan bahwa beberapa metode untuk mendeteksi telur cacing pada sampel tinja individu telah banyak dijelaskan, dengan rentang kepekaan uji untuk diagnosis pada sapi adalah 43-91,9\%). Fascioliasis adalah penyakit zoonosis yang disebabkan oleh cacing trematoda yang ditularkan melalui siput. Penyakit ini menyebabkan kerusakan hati. Pada hewan, penyakit ini menyebabkan kematian, hambatan pertumbuhan, penurunan produksi dan pengafkiran hati yang terinfeksi selama inspeksi daging (Nyirenda et al., 2019). Tiara, et al (1997), menduga bahwa hati mentah yang mengandung Fasciola spp immature apabila dimakan manusia dapat menyebabkan fasciolasis. Ditambahkan pula oleh Mas-Coma (1999) bahwa manusia merupakan hospes aksidental yang akan terinfeksi cacing aapabila secara tidak sengaja memakan metaserkaria dari Fasciola spp. 


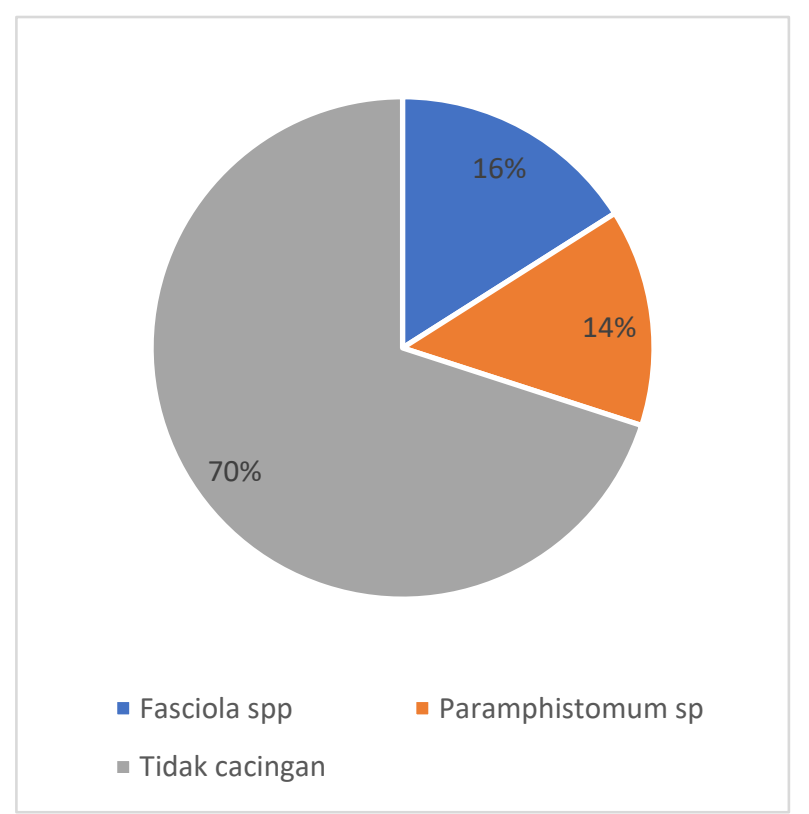

Gambar 3. Persentase kecacingan pada hewan kurban

\section{RUMEN}

Sebanyak 89 rumen $(13,57 \%$ ) (Gambar 3) yang diperiksa positif terinfestasi parasit cacing dan teridentifikasi sebagai Paramphistomum sp. (Gambar 2f). Hasil ini lebih kecil jika dibandingkan dengan hasil penelitian Darmin et al. (2016) yang menyatakan bahwa prevalensi paramphistomiasis pada sapi Bali di Kecamatan Libureng, Kabupaten Bone sebesar 57\%. Paramphistomum sp. menyebabkan kerugian pada petani peternak karena menyebabkan diare dan kekurusan ternak. Selain itu akan menurunkan kualitas daging disebabkan rusaknya jaringan terutama di saluran pencernaan. Laporan tentang infeksi Paramphistomum sp. pada manusia (zoonosis) belum pernah dilaporkan (Baker, 2007).

Jenis pemeliharaan dengan cara diumbar meningkatkan resiko infeksi atau penularan penyakit antar ternak, karena kontak antara ternak sakit dengan ternak sehat sulit dihindari (Akoso, 1996; Soebronto, 2001). Selain penyakit zoonosis, terdapat penyakit yang disebabkan oleh makanan (food borne diseases). Setidaknya terdapat 45 penyakit pada hewan yang dapat ditularkan melalui makanan, baik yang disebakan oleh bakteri, fungi maupun parasit (CDC, 2014).

\section{PENGAMATAN PROTOKOL KESEHATAN COVID-19}

Sebagian besar tempat penyembelihan telah melaksanakan protokol kesehatan berupa pemeriksaan suhu tubuh (Gambar 4a) dan wajib cuci tangan (Gambar 4b) saat memasuki area penyembelihan. Sebagian besar petugas jagal, petugas daging dan petugas jeroan telah mengenakan masker, terutama pada awal-awal pelaksanaan penyembelihan (Gambar 4c-e). Meski telah diupayakan dengan memisahkan tempat penanganan daging (daging dan jeroan) namun physical distancing dan menghindari kerumuman sulit dilaksanakan pada saat pelaksaan penyembelihan (Gambar 4f). Udara panas dan kerja yang membutuhkan banyak tenaga diyakini sebagai penyebab banyak petugas lalai mengenakan masker dan menerapkan physical distancing terutama pada pertengahan dan akhir dari waktu penyembelihan dan penanganan daging. Demikian pula untuk mencuci tangan dengan sabun, sebagian besar petugas telah mencuci tangan secara rutin akan tetapi tidak menggunakan sabun. 

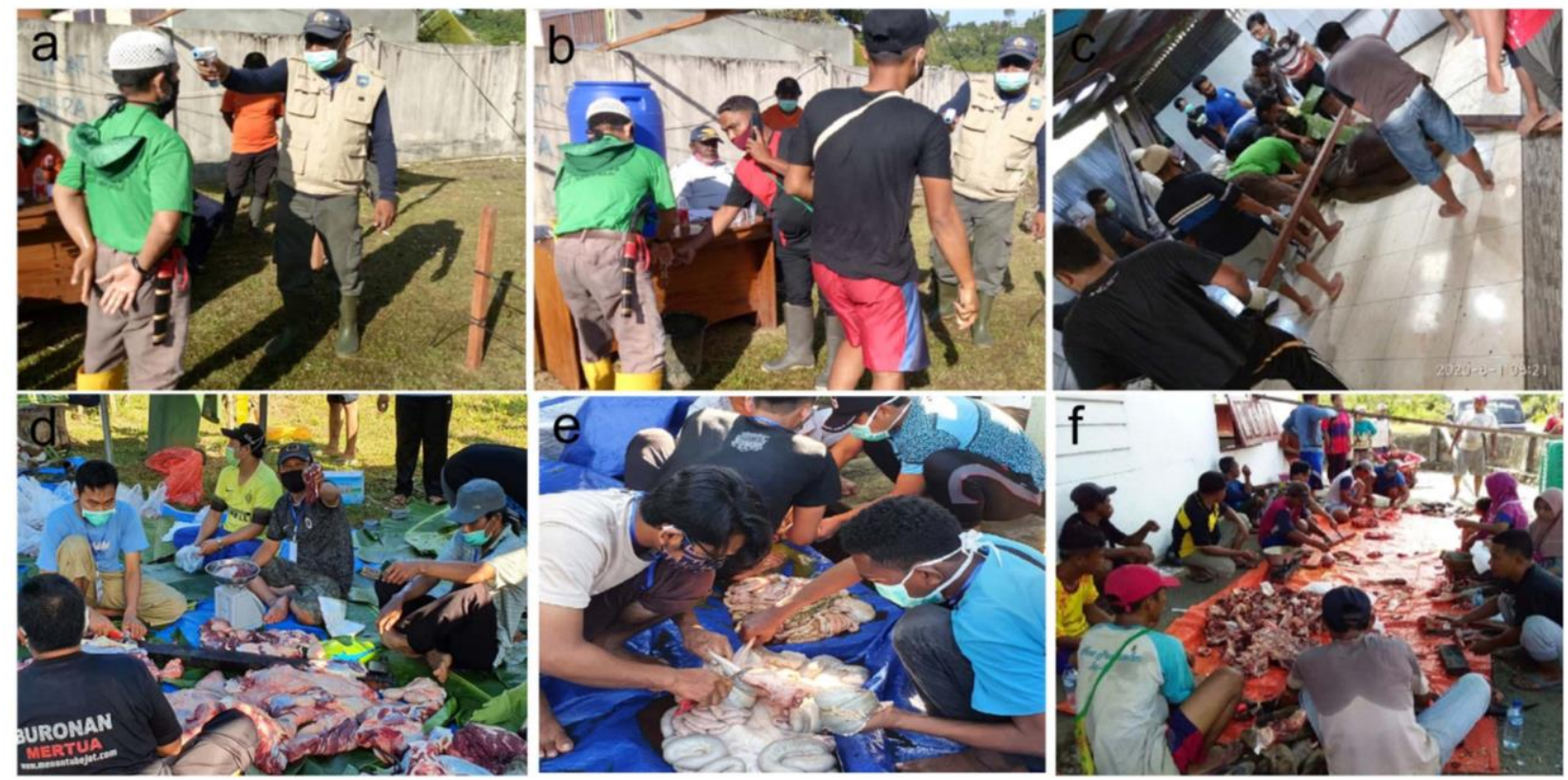

Gambar 4. Penerapan protokol kesehatan covid-19. (a) Pemeriksaan suhu tubuh pada petugas; (b)

Cuci tangan sebelum memasuki area penyembelihan; (c) Petugas jagal bermasker; (d) Petugas daging bermasker; (e) Petugas jeroan bermasker; (f) Kerumunan pada penanganan daging hewan kurban

\section{KESIMPULAN}

Berdasarkan pemeriksaan antemortem, seluruh sapi yang dipotong sebagai hewan kurban memiliki kondisi tubuh yang sehat. Berdasarkan pemeriksaan postmortem, terdapat infestasi cacing pada organ dalam sapi yang dipotong sebagai hewan kurban. Seluruh daging yang diperiksa layak untuk dikonsumsi. Protokol kesehatan covid-19 telah diupayakan sesuai anjuran pemerintah.

\section{UCAPAN TERIMA KASIH}

Ucapan terima kasih diberikan kepada Pemerintah Kabupaten Manokwari melalui Dinas Pertanian dan Ketahanan Pangan yang telah memfasilitasi kegiatan ini.

\section{DAFTAR PUSTAKA}

Akoso B T, 1996, Kesehatan Sapi, Penerbit Kanisius, Yogyakarta.

Baker DG. 2007. Flynn's Parasites of Laboratory Animals. $2^{\text {nd }}$ edition. Blackwell Publishing. Iowa.0 USA.

CDC. 2014. Food Safety. Centers for Disease Control and Prevention. Atlanta. USA.

Darmin SP, Yuliza F, Sirupang M. 2016. Prevalensi Paramphistomiasis Pada Sapi Bali Di Kecamatan Libureng, Kabupaten Bone. JIIP 2(2): 149-161.

Dinas Pertanian dan Ketahanan Pangan Kabupaten Manokwari. 2020. Laporan Jumlah Pemotongan Hewan Kurban Tahun 2020. Dinas Pertanian dan Ketahanan Pangan Kabupaten Manokwari. Manokwari.

Dirjen PKH. 2020. Buku Saku Pelaksanaan Pemotongan Hewan Kurban dalam Situasi Wabah Bencana Nonalam Corona Virus Disease (Covid-19). Direktorat Jenderal Peternakan dan Kesehatan Hewan. Kementerian Pertanian RI. Jakarta.

Graham-Brown J, Williams DJL, Skuce P, Zadoks RN, Dawes S, Swales H, Van Dijk J. 2019.

Composite Fasciola hepatica faecal egg sedimentation test for cattle. Veterinary Record. 184(19): 1-8.

Hadi RW, Setiawan I dan Sumardi. 2011. Perancangan Alat Pendeteksi Kualitas Daging Sapi Berdasar Warna dan Bau Berbasis Mikrokontroler Atmega32 Menggunakan Logika Fuzzy. Transmisi. 13(1): 21-26 
Mas-Coma MS, Esteban JG, Bargues MD. 1999. Epidemiology of human fascioliasis: a review and proposed new classification. Bulletin of the World Health Organization. WHO.

MUI, 2009. Fatwa MUI Nomor 12 tahun 2009 tentang Standar Sertifikasi Penyembelihan Halal. MUI Pusat Bidang POM dan IPTEK. Jakarta.

MUI, 2020. Fatwa MUI Nomor 36 tahun 2020 tentang Shalat Idul Adha dan Penyembelihan Hewan Kurban saat Wabah Covid-19. Majelis Ulama Indonesia Pusat. Jakarta.

Nyirenda SS, Sakala M, Moonde L, Kayesa E, Fandamu P, Banda F and Sinkala Y. 2019. Prevalence of bovine fascioliasis and economic impact associated with liver condemnation in abattoirs in Mongu district of Zambia. Veterinary Research.15(33): 1-8.

Purwaningsih, Noviyanti, dan Putra RP. 2017. Distribusi dan Faktor Risiko Fasciolosis pada Sapi Bali di Distrik Prafi, Kabupaten Manokwari, Provinsi Papua Barat. Acta Veterinaria Indonesiana. 5(2): 120-126.

Subronto. 2001. Ilmu Penyakit Ternak II. Gadjah Mada University Press. Yogyakarta.

Tainmeta HA, Kune P, Lay WA. 2016. Hubungan skor kondisi tubuh dan berat badan induk sapi bali dengan berat lahir dan berat badan pedet umur satu bulan. Jurnal Nukleus Peternakan. $3(1): 17-23$

Taira N, Yoshifuji H, Boray JC. 1997. Zoonotic potential of infection with Fasciola spp. by consumption of freshly prepared raw liver containing immature flukes. International Journal for Parasitology, 1997, 27: 775-779. 